Bangladesh J. Sci. Ind. Res. 43(1), 97-102, 2008

\title{
Nutritional Status of School Going Children of a Selected School of Dhaka City
}

\author{
Mohajira Begum and Zaibun Nessa \\ Biochemistry and Applied Nutrition Division, \\ IFST, BCSIR, Dhaka, Bangladesh.
}

\begin{abstract}
Nutritional status of 327 boys and girls attending a high school in Dhaka City has been reported in this study. Weight for age (Wt/Age), height for age (Ht/Age) and weight for height $(\mathrm{Wt} / \mathrm{Ht})$ of the study participants were calculated and compared with the National Center for Health Statistics (NCHS) reference standards. Only 0.6\% children were severely stunted and $4.3 \%$ were moderately stunted. In addition, $3.7 \%$ children were moderately wasted and $0.6 \%$ children were severely wasted. One girl was severely and $2.1 \%$ children were moderately underweight level. The overall nutritional status of the study samples was better than country situation and cannot be the similar to that of same age group of population of the country. Here, the children of the privileged class represent a typical group of population of the city.
\end{abstract}

Key words : Nutritional value, School student, Weight per age and height.

\section{Introduction}

Malnutrition is one of the principle public health problems, affects large numbers of children in developing countries. In Bangladesh, various survey reports show that approximately $85 \%$ of the people intake insufficient food, $76 \%$ of rural households are deficient in protein intake and 93\%, 88\% and $87 \%$ of households had deficient intake of calcium, Vitamin A and Vitamin $\mathrm{C}$ respectively, About $54 \%$ of the children aged $0-11$ years are stunted, $5 \%$ of the children are wasted, $10 \%$ of the children are simultaneously stunted and wasted. Moreover, $75 \%$ of the children suffer from iron deficiency
anaemia(INFS, 1983). About one million out of the 23 million children in the country suffer from Vitamin A deficiency disorders (IPHN,UNICEF,1989) and $21.6 \%$ of school age children had serum retinal values below 0.7 umol/liter(HKL-IPHN, 1999). Studies on the nutritional condition of urban areas are highly limited. A very few studies were carried out regarding nutritional situation of children in urban areas. Among the total population of Bangladesh the children (age 0-9 years) consists of $33.3 \%$. The report of Bangladesh Bureau of Statistics shows that prevalence of underweight (W/A below - 
2SD Score) children (6-71 month) is $51.1 \%$ wasted (W/H below-2SD score)is $11.7 \%$ and stufvted (H/A. below - 2SD Score) is $48.8 \%$ (BBS, 2001).

Childhood is a period of the active growth and school aged children passes the active growing phase of their life (Nutrition, 2002). The national nutrition survey (1995-96) report shows that about $62 \%$ of the children aged 6-9 years are malnutrition's, $43.4 \%$ of the children are stunted but not wasted and $9.3 \%$ of the children are wasted but not stunted. In addition, $9.1 \%$ of the children are both stunted and wasted (Jahan and Hossain, 1998).

In this report an effort was made to study the health and nutritional condition of urban children. Here the nutritional status of school going children above four years of age in a selected school of Dhaka City by anthropometric measurement is furnished.

\section{Materials and Methods}

The study was carried out in BCSIR High School situated in central part of Dhaka City. Students of the schools are from high socioeconomic groups of family. The school has both primary and secondary classes and runs two shifts, morning shift for the girls, nursery to class $\mathrm{HI}$ for the boys and evening shifts for only boys students. The present study covered the morning shift and determined the nutritional status of the children. The measurements were recorded from August 2001-October 2002. The age of the students were determined from the register of the school. Only those children who were listed in the register to be in the age group of 4 to 10 years. The measurement were done with school uniform and without shoes. The nutritional status of students in relation to their age, body weight are compared with the National Center for Health Statistics (NCHS) reference standards (National, 1990).

\section{Result and Discussion}

Table I shows the distribution of age and sex of the study children. There were 177 . boys and 150 girls representing 54.13\% and $45.87 \%$ of the students, respectively. There were 13 students having age below 4 years and therefore were not included in the study.

Table I. Age and sex distribution of children

\begin{tabular}{c|c|c|c}
\hline Age in years & Boys & Girls & Total \\
\hline $4-5$ & $52(15.90)$ & $55(16.82)$ & $107(32.72)$ \\
$6-7$ & $89(27.22)$ & $57(17.43)$ & $146(44.65)$ \\
$8-9$ & $36(11.01)$ & $38(11.62)$ & $74(22.63)$ \\
Total & $177(54.13)$ & $150(45.87)$ & $327(100.00)$ \\
\hline
\end{tabular}

Table II shows the anthropometric measurements compared to the standards (National, 1990). The body weight of the boys ranged between $116 \%$ and $92 \%$ of the standards with the increase of age, the body weight shows slight decrease but the decrease was insignificant. The body height ranged between $110 \%$ and $97 \%$ of the standard. The body height of the boys also showed insignificant decrease with the increase of age. 
Table II. Anthropometric measurements of boys and comparison with standard.

\begin{tabular}{c|c|c|c|c|c}
\hline $\begin{array}{c}\text { Age } \\
\text { Year }\end{array}$ & $\begin{array}{c}\text { No. of } \\
\text { Boys }\end{array}$ & $\begin{array}{c}\text { Weight (kg) } \\
\text { Mean } \pm \text { SD }\end{array}$ & $\begin{array}{c}\text { Std wt. } \\
(\%)\end{array}$ & $\begin{array}{c}\text { Height (cm) } \\
\text { Mean } \pm \text { SD }\end{array}$ & $\begin{array}{c}\text { Std. ht. } \\
(\%)\end{array}$ \\
\hline 4 & 20 & $19.35 \pm 3.30$ & 115.87 & $112.91 \pm 7.78$ & 109.73 \\
5 & 32 & $19.61 \pm 3.37$ & 104.87 & $112.08 \pm 6.12$ & 101.98 \\
6 & 29 & $22.36 \pm 4.85$ & 108.02 & $118.90 \pm 7.28$ & 102.41 \\
7 & 60 & $25.36+5.58$ & 110.74 & $125.16 \pm 8.14$ & 102.83 \\
8 & 31 & $28.66 \pm 9.39$ & 113.28 & $130.03+5.86$ & 102.39 \\
9 & 5 & $26.00 \pm 3.31$ & 92.23 & $127.00 \pm 3.22$ & 96.07 \\
\hline
\end{tabular}

Std = Standard; wt= weight; ht= height

Table III shows the anthropometric measurements compared with the standards (National, 1990). The body weight of the girls ranged between $109 \%$ and $91 \%$ of the standards. The body weight shows slight decrease with the increase of age, so the decrease was insignificant. The body height ranged between $107 \%$ and $98 \%$ of the standard. Similar to body weights, the heights further showed insignificant. moderate stunted. There were 311 (95.1 \%) children had normal level.

Table V shows that highest i.e. 319 (97.6\%) of children had normal nutritional status. In addition, 7 (2.1\%) and 1 (.3\%) of children had moderate and severe under weight respectively. The nutritional status of the children according to compared with the National Center for Health Statistics (NCHS)

Table III. Anthropometric measurements of girls and comparison with standard.

\begin{tabular}{c|c|c|c|c|c}
\hline $\begin{array}{c}\text { Age } \\
\text { Years }\end{array}$ & $\begin{array}{c}\text { No. of } \\
\text { Girls }\end{array}$ & $\begin{array}{c}\text { Weight }(\mathrm{kg}) \\
\text { Mean } \pm \text { SD }\end{array}$ & $\begin{array}{c}\text { Std } \\
(\%)\end{array}$ & $\begin{array}{c}\text { Height }(\mathrm{cm}) \\
\text { Mean } \pm \text { SD }\end{array}$ & $\begin{array}{c}\text { Std. ht } \\
(\%)\end{array}$ \\
\hline 4 & 20 & 17.5012 .19 & 109.38 & $108.48 \pm 5.72$ & 106.77 \\
5 & 35 & $19.14+3.58$ & 108.14 & $109.76 \pm 6.67$ & 101.25 \\
6 & 25 & $19.46 \pm 2.92$ & 99.79 & $112.71 \pm 6.88$ & 98.35 \\
7 & 32 & $21.33 \pm 4.35$ & 99.84 & $120.44+6.55$ & 99.87 \\
8 & 20 & $26.93+5.35$ & 108.59 & $128.96 \pm 4.97$ & 102.03 \\
9 & 18 & $25.89+2.90$ & 90.82 & $129.92 \pm 4.39$ & 98.28 \\
\hline
\end{tabular}

Std = Standard; wt= weight; ht= height

Table IV shows that only 2 (0.6\%) children were severe stunted and $14(4.3 \%)$ were reference standards have been shown in Table VI. There were only 2(0.6\%) children 
Table IV. Height for age Z-score (stunting)

\begin{tabular}{l|c|c}
\hline & Frequency & Percent \\
\hline 1.00 severe- 3.00 SD and below & 2 & 0.6 \\
\hline 2.00 Moderate- 2.99 SD to- 2.00 SD & 14 & 4.3 \\
3.00 Not stunted above- 2.00 SD & 311 & 95.1 \\
\hline Total & 327 & 100.0 \\
\hline
\end{tabular}

SD = Standard Deviation.

Table V. Weight for age Z-score (under weight)

\begin{tabular}{l|c|c}
\hline & Frequency & Percent \\
\hline 1.00 severe- 3.00 SD and below & 1 & 0.3 \\
\hline 2.00 Moderate- 2.99 SD to- 2.00 SD & 7 & 2.1 \\
3.00 Not underweight above- 2.00 SD & 319 & 97.6 \\
Total & 327 & 100.0 \\
\hline
\end{tabular}

SD $=$ Standard Deviation.

had severe wasted, 12 (3.7\%) children had moderate wasted level and 313 (95.7\%) children had not wasted or nutritional status normal.

Table VII shows the nutritional status of school going children. The number of children having normal nutritional status was 288 (881.1\%), wasted 14 (4.3\%), stunted 16 (4.9\%), both wasted and stunted 9 (2.7\%).

The present study represents the nutritional status of children aged above four years from an posh area of the central part of Dhaka City. It can be stated that this study cannot represent the nutritional status of children of the same age group from the whole country. The childhood period is very vital phase as this is the rapid growing stage of human life. Moreover, children are more vulnerable to disease, death and disability owing to their age, sex, socio-economic class and a host of other variables (Park's, 2001). A study in 1990 observed that the nutritional status of school going children in Bangladesh showed that $26.2 \%$ of he children had normal in all the parameters, $47.3 \%$ wasted, $14.3 \%$ stunted and $12.2 \%$ were both wasted and stunted (Ahmed, R. Kabirullah, M. Shahjahan, M. Nessa, Z. Miah, S. Khan, S.A. 1990). And other study in 1990 showed that $51 \%$ of the children had normal and $15 \%$ stunted, $32 \%$ wasted and $2 \%$ both stunted and wasted. (Karim, R. Bhuyan, M. A. H. 1990).

While the National Center for Health Statistics (NCHS) reference standards were 
Table VI. Weight for height Z-score (Wasting)

\begin{tabular}{l|c|c}
\hline & Frequency & Percent \\
\hline 1.00 severe- 3.00 SD and below & 2 & 0.6 \\
\hline 2.00 Moderate- 2.99 SD to- 2.00 SD & 12 & 3.7 \\
3.00 Not wasted above- 2.00 SD & 313 & 95.7 \\
\hline Total & 327 & 100.0 \\
\hline
\end{tabular}

SD = Standard Deviation.

Table VII. Nutritional status of school going children

\begin{tabular}{l|c|c}
\hline \multicolumn{1}{c|}{ Nutritional status } & Number of children & \% of the total \\
\hline Normal & 288 & 88.1 \\
\hline Wasted & 14 & 4.3 \\
Stunted & 16 & 4.9 \\
Both wasted and stunted & 9 & 2.7 \\
\hline Total & 327 & 100.0 \\
\hline
\end{tabular}

used, it was found that out of 327. Only I (.3\%) children had severe wasted and 2 (.6\%) children had severe stunted level. The present study showed better nutritional status of the targeted school going children in compare to other reports (INFS, 1983. BBS, 2001. Jahan and Hossain, 1998. Ahmed, et al 1990 and Karim, et al 1990). This is possible due to the study samples were from a privileged class of higher socio-economic family and this cannot be compared to the national findings of nutritional status of the same age group of population of the country. Usually, the parents like to reduce the age of children in school which might affect the calculation of nutritional status showing better perform ance than the actual situation. The parents of urban areas are more health conscious than that of rural areas. The role of mass media has great importance in this regard. The government has taken some important initiatives (e.g. vaccination, vitamin capsule distribution, maternal child health program and birth certificate registration etc). However, these activities need to be more strengthen to improve the present situation.

\section{Acknowledgement}

The authors gratefully acknowledge to Dr. M. Zahirul Haque Bhuiyan, Director, Institute of Food Science and Technology, BCSIR for providing necessary support to conduct the study. 
Children's Fund (1989):1.

The authors also extended acknowledge to Dr. M. Kabirullah, Ex-Member (Dev.), BCSIR and Rukonuddin Ahmed, Ex-Chief Scientific Officer, Institute of Food Science and Technology BCSIR for their co-operation and valuable suggestions during the study period.

The authors are also grateful to National Science and Information \& Communication Technology (NSICT) for financial supports.

\section{References}

Ahmed, R.Kabirullah, M. Shahjahan, M. Nessa, Z. Miah, S. Khan, S. A.(1990). Nutritional status of school going children in Bangladesh, DS (child) $H J$ 6(1):13.

Bangladesh Bureau of Statistics. Statistical Pocket Book. Statistics Division, Ministry of Planning, Government of the Peoples Republic of Bangladesh, (2001):134:381.

HKI-IPHN, Vitamin A status throughout the Lifecycle in rural Bangladesh' Helenkeller International and Institute of Public Health Nutrition, Bangladesh, (1999):19.

INFS, 'Nutrition Survey of Rural Bangladesh 1981-82. Institute of Nutrition and Food Science, University of Dhaka, Dhaka, (1983).

IPHN/UNICEF, Nutritional Blindness Prevention Programme Evaluation Report. Institute of Public Health Nutrition and United Nations
Jahan, K. and Hossain, M.(1998) Nature and Extent of Malnutrition in Bangladesh. Bangladesh National Nutrition Survey, 1995-96, Institute of Nutrition and Food Science, University of Dhaka, July, Part-1, 116:134.

Karim R.Bhuyan, M. A. H. and Sukanta, $S(1990)$. Nutritional status of children in an Urban primary school in Dhaka. Bangladesh Journal of Nutrition, 4(1): 5361.

Nutrition for the school-aged child. G92-1086-A, April, 2002:1.

National house hold survey capability programme (1990). Assessing the Nutritional status of young children. United Nations Department of Technical Cooperation for Development and Statistical Office, DPAJNANT-8S-X01/8E, New York.

Park's Text Book of Preventive and Social Medicine 16th Ed. 2001.

Received : January 03, 2004;

Accepted : December 29, 2005 